\title{
GANDHIAN MODEL OF COMMUNITY DEVELOPMENT
}

Badal Bharat Prasad ${ }^{1 *}$

\begin{abstract}
Gandhian Model of Community Development (GMCD) is a sustainable development model for governments in the central, provincial, and local levels of democratic federal countries in the world by the scientific analysis of Gandhian ideology in a specified community. Community Development is a method, a strategy, and a campaign to uplift human life settlements and to solve the community problems from a simple local perspective. The human settlement with local communal acceptance, local norms, and values, environmental protection, help and cooperation, trusteeship, health, education, sanitation, training, transportation, marketing, etc. are the major components of the Gandhian Model of Community Development. The global acceptance with local initiation, norms, knowledge and practices in the positive changes on human life is Gandhian Community Development. It is the core ideological view of the great leader of south Asia-Mahatma Gandhi. Mahatma Gandhi is also pronounced as second Buddha of the world.
\end{abstract}

The main objective of the study is to develop a Gandhian Model of Community Development with the incorporation of thoughts and ideologies of Mahatma Gandhi. The study is the collection of Gandhian ideology with a programmatic model for the future development of the human being specified within the boundary with the specified indicators of the Gandhian Model of Community Development. It is a hermeneutic and historical interpretation of three universal truths-Generation, Operation, and Destruction for the liberation of human beings from a sustainable development strategy guided by Mahatma Gandhi. His ideas are herminuted in contemporary sustainable community development. In conclusion, the Gandhian Model of Community development is a model having Balance Sheet of Production and Consumption within the specified municipality and Gandhian Development Indicators for human liberation or development toward ultimate freedom.

\section{Keywords}

Liberation, Mahatma Gandhi, Model, Community Development, Sustainable Development

\section{Introduction}

$1{ }^{*}$ Dr. Badal is Associated with Tourism, Research and Development, is editor-in-chief of Research Nepal Journal of Development Studies, can be corresponded at bpb222@yahoo.com 
Gandhian Model of Community Development (GMCD) is the Model of Development based on the philosophy of Mahatma Gandhi- a great Indian freedom fighter of the 20th century. According to him, nature has given enough for humans to satisfy but not for the greedy people. Every local has sufficient natural resources that the real expert can expertly mobilize it for the betterment of the people. The problem is its optimum mobilization and utilization. The Community development means optimum production of Agriculture and allied activities in the Community, including the development of cooperatives and cottage industries. It gives more than employment opportunities in Community especially for the weaker section of the sector so as to enable them to improve their socio-economic status. Gandhi wanted to bring about Community reconstruction with scientific and spiritual values. He had identified and successfully implemented an 18-point program (Yesu \& Muthupandi, 2016). These 18-points and other important points are included in the study to develop the model. He wanted to bring about Community reconstruction and development with sound scientific and spiritual values. Through his 18-point Constructive Programs, Gandhi had successfully implemented his Community reconstruction activities in Sevagram Centre near in Wardha in 1935. But still, the model and practice of the Gandhian Model have not been applied in development. His concept of Community reconstruction is a comprehensive one, emphasizing the economic, political, social, educational, ecological, and spiritual dimensions of humanism.

Gandhian development model that emphasizes on the decentralization. and the local-centric economy can be used as an alternative development model for the economy after the revival of the COVID-19 pandemic situation (Tiwari, 2020). This paper is very relevant in this situation as well. The Gandhian model which was guided by a humanistic, ethical, and sustainable development approach, The Gandhian economic development model can help to sustain the economy in any world-wide pandemic or war-kind situations.

One of the greatest exponents of all-round sustainable development, without naming the term, was Mahatma Gandhi. Gandhi talked about all-round sustainable development which is applicable in each and every aspect be it environment, personal physical, mental and spiritual health, politics, economics, and law and justice. Perhaps, there is no greater exponent and intricate visionary of sustainable development for the human race than Gandhi. His books 'Hind Swaraj', 'My NonViolence', 'Story of My Experiments with Truth', 'Law and Lawyer', etc. discuss at length various aspects of sustainable development for an individual, industry, nation, and humanity as a whole without the nomenclature (Vaishnav, 2014).

The decentralized local economy should provide full employment to all on the basis of voluntary cooperation and work for achieving self-sufficiency in it is a basic requirement of food, clothing, 
and shelter. "My idea of Local Swaraj is that it is a complete republic, independent of its neighbors for its own vital wants and get inter-dependent for many others in which dependence is a necessity. The 18-point Constructive Programs included the following Items: I. Communal unity, 2. Removal of untouchability, 3. Prohibition, 4. Khadi, 5. Other Local industries, 6. Local sanitation, 7. New or basic education, 8. Adult education, 9. Women, 10 Education in health and hygiene, 11 Provincial languages, 12 National languages, 13 Economic equalities, 14 Kisans, 15 Labor, 16 Adivasis, 17 Lepers, and 18. Students (Panday, 1991). Gandhian Model to approach Community development strives to reconstruct local republics which would be non-violent, self- governed, and self-sufficient so far as the basic necessities of Community people. Thus, including the entire these points, the model has been developed. Gandhi believes that the mother nature in entire integration is God. Everything on this earth belongs mother nature.

\section{Objectives}

The study is aimed to make Gandhian Model of Community Development. To develop the Gandhian concept into a development model by the analysis of the basic indicators on Governances of Governments, the study is being prepared. The model will be the model of development program for governments and researchers of the development studies, social works, population, political sciences, economics and other social sciences for the future researches.

\section{Methodology}

The study is based on the qualitative analysis of an intensive literature review. It is a hermeneutics of Gandhian philosophy in sustainable development and historical interpretation of three universal truths- Generation, Operation, and Destruction for the liberation of human beings. It is a sustainable development strategy guided by Mahatma Gandhi for different actors of development of community. It is the collection of Gandhian literature to form a development model of local governments. The idea of the model local is old, whereas the question of what elements makeup a model local is still a new - and perplexing. It is new because development is a process of continuous change in a variety of aspects of human society.

Hermeneutics: Gandhian theological views and meanings are reinterpreted and the interpretations are tested with historical facts and biography of Gandhi as evidence of history. The interpreted historical facts are matched with the philosophy of sustainable development and results are drawn in each paragraph of the text. At the outset of the modern age humanism, promoting the study of classical antiquity, and the reformation, promoting the principle of biblical study for all within the Christian world, gave new and important impulses to the direction in which hermeneutics 
itself was to develop (Amoroso, 2015). A central hermeneutic issue in theology is the relation of divine revelation to human understanding. Interpretation, we have argued, entails the faithful translation of what someone has said about a certain matter into our own meaning context. The interpreter is essentially a mediator who relates the meaning of another's communication to present circumstances (Zimmermann, 2015). Thus, the theological ideology of Mahatma Gandhi is translated into the community development. Community is theological and religious bondages of human being as a group.

Historiography: History of interpreted facts are tested and evaluated with available literature. The historiographic narrative is the final result of historiographic research written in narrative form like textbooks (Pitcher, 2009, p. 87). Historiographic research is the professional activity of historians. Historiography is what historians write, about past events, about history. For example, Leopold Ranke's History of the Popes. History is past events, processes, etc. The decline and fall of the Roman Empire in written form is a suitable example of historiography. Natural historians or historians of nature are the people who write about natural history (Tucker, 2009, p. 9). The study of the history of historical writing - by presenting an accessible and concise overview of the history of historical writing from the renaissance to the present, focusing primarily (Deliyannis, 2003, p. 35), (Gelina, Nikos, Kostas, \& Vaiopoulos, 2010, p. 24). Historiography is a continuous dialogue, always marked by new perspectives that enrich the understanding of the past but which themselves are replaced by other perspectives. Thus the study is the political history of $20^{\text {th }}$ century of south Asia from Gandhian ideology.

Sustainable Development: Gandhian thoughts are analyzed and intermingled with the philosophy of sustainable development to draw the conclusion. The 17 Sustainable Development Goals and 169 targets that demonstrate the scale and ambition of this new universal agenda. These agendas are based on the Millennium Development Goals and complete what these did not achieve. The basic human rights of all and to achieve gender equality and the empowerment of all women and girls are also addressed. These are integrated and indivisible and balance the three dimensions of sustainable development: the economic, social, and environmental (Hambrey, 2017). The Goals and targets stimulate action over the next fifteen years in areas of critical importance for humanity and the planet.

\section{Result}

Liberation $=$ Balance(Equanimity) of materialism and spiritualism in human life =Balance of Karma, Artha, Dharma, and Moxya 
= Balance of social, economic, political-environmental, and spiritual life

$=$ Balance of (Natural and Human) Resources in Local

$=$ Coexistence of nature and human

$=$ Balance between production and consumption

Liberation or freedom is development. Community Development is Development of (Economy, Society, Environment) in locality. Community Development is Development of (Income, Employment, Health, Education, Optimum Utilization of Natural Resources) in local level. Socio economic and environmental development lead to: The aggregation of Karma, Artha, Dharma, and Moxya is the ultimate goal of human development or life. Karma and Artha are material goals whereas Dharma and Moxya are socio psychological (sometime Spiritual) goals. It must be analyzed qualitatively as well as quantitatively. Rural Development (RD) = Development of Local natural and human resources (Badal, 2017). Similarly, Gandhian Model of Community Development is Development of Local Natural plus Human Resources. GMCD $=$ D of (NR+ HR) Where $D=$ Community Development, $D=$ Development, $L R=$ Local Resources, $N R=$ Natural Resources, HR= Human Resources.

From the Gandhian Perspective core value of Community Development is fulfillment and achievement of Basic needs, self-respect and freedom of local. Therefore, Community Development is development on Basic needs, self-respect and freedom of specified municipality. Thus community development is also the development, management and mobilization resources sustainably in a community.

From the Gandhian literature we can say, Moxya- enlightenment, less consumption, cottage industry, sustainable livelihood, environment protection, simple living high thinking, and spiritually conscious material sciences are the basic features of Gandhian Model of Community Development (GMCD) for a particular government in its territory.

\section{Discussion}

\section{Biography of Gandhi}

Gandhi says: 'The world of tomorrow will be, must be, a society based on non-violence. It may seem a distant goal, an unpractical utopia' to the modernity. But it is not in the least unobtainable, since it can be worked from here and now (Prabhu, Rao, Bhave, \& Radhakrishnan, 1967). In every respect, Kumarappa was a truly strong Gandhian and the economic development visions of both 
were the same or very similar. It was he who coined the term 'Gandhian economics.

Mohandas Karamchand Gandhi, commonly known as 'Mahatma' - Great Soul was born in Porbandar, Gujarat, in northwest India, on $2^{\text {nd }}$ October 1869 , into a Vedic family. His father was the Chief Minister of Porbandar, and his mother was a religious in devotion meant that his upbringing was infused with the Jain pacifist teachings of mutual tolerance, non-injury to living beings, and vegetarianism. In May 1883, aged 13, Gandhi was married to Kasturba, a girl also was aged 13, through the arrangement of their respective parents, as was customary in previous India. Following his entry or involvement into Samaldas College, at the University of Bombay, she bore four sons, Gandhi was unhappy at college, following his parent's wishes to take the bar, and when he was offered the opportunity of furthering his studies overseas, at University College London, aged 18, starting there in September 1888.

80 years before the formation of the Bruntland commission for "Our Common Future" in 1908 Gandhi has raised the questions of sustainable development in his magnum opus- Hind Swaraj. Modernism was in pick position so the entire world including India did not pay attention to the Gandhian notions. After modernism and even postmodernism in the era of Sustainable Development Goals, the entire world has accepted his ideology but in a different way. The problems that he identified decades ago still remain the most pressing yet unsolved economic problems of our time-poverty, inequality, unemployment, and environmental degradation. He initiated and launched the first Satyagraha in 1906 which lasted for eight years and was ended in 1914. Based on truth and non-violence it stressed the simplicity of life, unity of all religions, and of the entire mankind (Sahu, 2016). Through his book "The Hind Swaraj" he outlined the threat to the common future of humanity caused by the relentless quest for more material goods and services. He described the modern western civilization driven by endless multiplication of wants as Satanic and defined oriental civilization in terms of performance of duties, adherence to morality, and exercise of restraint. Any approach which puts limitations on passion and greed and which aims at fulfilling the fundamental needs remain central to the concept and practice of sustainable development. The Hind Swaraj became a manifesto of sustainable development.

J.C. Kumarappa had always adored and accepted Gandhian thoughts in full of sincerity. Gandhi's devotion to Truth and Non-violence is the one that attracted him the most. He believed that at a time when the world is steeped in violence, wickedness, unfaithfulness, and false propaganda, Gandhi's principles alone can save and beckon the world (Pillai, 2018). The love of Kumarappa for Gandhian views is evident from his article "Gandhian Economy and The Way to Realize It," published by Gandhi Seva Gram Ashram, Wardha as part of their 'Articles Series' on 'Gandhian 
view on Economics'. it gives a detailed view of the Gandhian Model of Community Development.

In August 1947, Great Britain granted independence, but the British Indian Empire was partitioned into two dominions - India and Pakistan as a Hindu-majority India and Muslim-majority Pakistan. As many displaced Hindus, Muslims, and Sikhs made their way to their new lands, so religious violence broke out. The official celebration of independence in Delhi, Gandhi visited the affected areas, attempting to provide solace. He undertook several fasts unto death to stop religious violence. The last of these, on $12^{\text {th }}$ January 1948 when he was 78, also had the indirect goal of pressuring India to pay out some cash assets owed to Pakistan. Some Indians thought Gandhi was too accommodating Muslims. Among them was Nathuram Godse, a Vedic nationalist, who assassinated Gandhi on 30th January 1948 by firing three bullets into his chest and fell down with the words "He Ram". Gandhi's birthday, $2^{\text {nd }}$ October, is commemorated in India as Gandhi Jayanti and a national holiday. It is celebrated worldwide as the International Day of Nonviolence. Gandhi is considered the Father of the Nation in India and was commonly called Bapu in Gujarati: endearment for father. Gandhi is an iconic and unique figure; his historic achievements, moral example, values, and methods continue to inspire and provoke debate (Cush, Robinson, \& York, 2008).

\section{Gandhian Community Development Thought}

Contemporary south Asia is working and slowly walking on the path of the Gandhian Model of Development. The Swachh Bharat Abhiyan and several flagship schemes for social justice such as Jan Dhan Yojana, Ayushman Bharat, Beti Bachao Beti Padhao are inspired by Gandhian spirit. Gandhiji believed that there can be no development unless everyone was benefitted including the Dalits, Minorities, and women. He worked tirelessly to bring those on the fringes of society into the mainstream (Reddy, 2019). Being one of the most discussed, studied, and followed human beings across the globe as the advocate of simplicity Ahimsa and forerunner of development in Community India, Gandhian philosophies have touched every aspect of Community India and established immediate links with the rhythm of Community heartbeats. When all models are wrong, more stringent quality and criteria are needed for models used the science-policy interface as required. Thus this model is applicable for Community development research.

\section{Core Values of Development-Liberation}

The Gandhian model of economic development is sustainable economic development in this sense and 'Development with Divinity.' All our current efforts to move towards sustainable development will be futile unless we accept and adopt Gandhian principles to exploit natural resources only 
to the minimum required for meeting the minimum consumption needs of the people and stop all extravagant consumption habits and lifestyles being promoted through aggressive marketing (Pillai, 2018). In this model, economy, polity, governance is evolved from below through an intensive engagement of people to achieve development.

Development is the journey toward liberation or complete freedom from any kind of human problem for future courses. It is not static in nature, it is dynamic and progressive in nature. Thus, Amartya Sen rightly says, the means and ends of development are freedom- the liberation. Thus development is eternal transcendental peace and progress of human life. It is enlightenment and it is Moksha. It is the availability of material as well as psychosocial facilities for the betterment of human life at the present and future. That is the culture of peaceful karma, transcendental truth, cleanliness of nature, and equanimity with the universal organisms in aggregation is development. There are only three universal truths in this universe that whatever we see and notice here was born or generated by and it has manifested with its name and quality or maintained or operated and die out. This generation operation and destruction are in a combined set is God is the truth. Thus, health, education, production, income, spiritual, and psychological transcendental peace and truth in the mind of Community people in Community development. It is the perfect balance of materialism and spiritualism.

The advent of the industrial revolution in Europe began the era of unsustainable development in the base of modernism. The unleashing of the creative energies of people during that period led to the spectacular progress in the field of science and technology. The tapping of energy from coal and the application of new methods of production gave rise to unprecedented productivity (Sahu, 2016). The theme of sustainable development has evolved with the evolution of human civilization. "The Living Planet" a report of the World Wild Life Foundation released in 2006 clearly stated that in the 1980s it was realized that the ways of life followed by western societies have disturbed the subtle balance of the planet earth and exploitation of natural resources. The Human Development Report 2007-08 on the theme Fighting Climate Change: Human Solidarity in a Divided World also critically looked at the modern development and wrote that climate change calls into question the Enlightenment principle that human progress will make the future look better than the past is in concern

Men and women will be free and able to hold their own against anyone in the world if they follow the principles of sustainability. Gandhi realized the need for integrated Community development and believe that education and health in the poorest section of society. According to him, education with consciousness is knowledge of power and health is the stamina of a person and 
society, his approach to Community development which would be non - violent. Self - governed, self - sufficient in regard to food, clothing, and shelter in Community areas through reducing Community poverty. He focused on the attention of agriculture and Non - Agriculture aspect of the Community economy through the all-round development of Community India (Yesu \& Muthupandi, 2016). Remove the untouchability, racial discrimination, and social evil and give the rights of people, which are enhancing social and political status. He was shared different concepts of Community development, if any doubt arises from the Gandhian approach of Community development it is clear about everything on his personal life. His life is his message. The basic principle of local Swaraj as outlined by Gandhi are trusteeship, swadeshi, full employment, bread labor, self-sufficiency, decentralization, equality, NaiTalim, etc.

\section{Assumptions of the Gandhian Model of Community Development}

The assumption is that this will create a model that can be used to describe some kind of reality of interest. The Gandhian model of governance, the entire focus of the decentralized model of governance is to ensure that in every way the individual is provided the required strength to move forward in life. Gandhi recommended a development path that incorporated the following principles-

1. Local self-sufficiency, especially in communities, which would give locals a significant measure of autonomy. Community farmers and agricultural producers would have a synergistic relationship in community development.

2. Rejection of modernization, particularly of labor-saving machinery. Gandhi preferred the provision of employment over the pursuit of high economic growth;

3. A simple lifestyle that was not dominated by materialism. He was against the enslavement of people by means of the temptation of luxuries that money can buy.

4. Sensitivity to the issue of environmental sustainability.

5. God manifests Himself in innumerable forms in the universe and every such manifestation commands my spontaneous reverence. GOD is (Generator, Operator, Destructor) mother nature.

6. Truth and non-Violence are the basic assumptions of Gandhi

His major contribution lies in evolving a framework of development which is now called an alternative model of development as the whole world moves in the western model of development, 
driven by the market and the other one, driven by the State. M. K. Gandhi's model of development relies on neither the market nor the State, it relies on the people. His framework of development essentially lies in harmony with nature when humanity interacts with nature (Palanithurai, 2019). the development model adopted by the market and the State has completely disrupted the harmony between human societies and nature by exploiting the environment and ecology.

\section{Elements of the Gandhian Model of Community Development}

\section{Self-sufficient Local Economy}

The fundamental concept of Sarvodaya described in 1942 by M.K. Gandhi in Hind Swaraj was the benefit of all, achievable through the autonomy of development for every Indian local (ColucciGray \& Camino, 2016). The local, as mentioned by Gandhi, should be self-sufficient for its basic needs - food, clothing, and other necessities - are concerned. The local, therefore, has to import certain things which it cannot produce in the local. It has to produce more of what it can, in order thereby to obtain in exchange, what they are unable to produce. Gandhi had a firm belief in naturopathy which shows his love for nature. In "Arogya Darshan" he has shared his experiences in relation to the natural diet and lifestyle of human beings. He wanted people to return to nature so that they can leave pseudo-diet and lifestyle and gain nature-based health in locals (Upadhyaya, 2015). It was he who founded the All India Local Industries Association (AIVA) in 1935. He was called 'the Green Gandhian' by the historian Mr. Ramachandra Guha, as he strongly stood for the environment and sustainable development. In every respect, Kumarappa was a truly strong Gandhian and the economic development visions of both were the same or very similar. It was he who coined the term 'Gandhian economics' (Pillai, 2018). Hind Swaraj is considered the foundational text by most Gandhian scholars, was written when Gandhi was returning from London to South Africa in a ship the Kildonan Castle, in 1909.

\section{Decentralization}

Gandhi believes that local republics can be built and new philosophy will establish only through the decentralization of the social and political power of people. In such a system decision-making power will be vested in the Local Council rather than in the State and the national capital, which is assured by the local democracy. The representatives would be elected by all adults for a fixed period of five years. The elected representatives would constitute a council, and govern the local. It exercises legislative, executive, and judicial functions. It would look after education, health. Sanitation and protect and uplift 'untouchables' and other poor people of the local. A non-violent peace brigade of volunteers would be organized to defend the local-like security personnel. The 
decentralized economic units, Palika or Panchayat or local councils would thus facilitate the best possible use of local raw materials, talents, and manpower, promote occupational equilibrium, ecological balance, and co-operative living in the local. The local would be able to produce whatever is required, with the help of local resources, and would be intended with whatever has been produced in closer surroundings (Sharma S. P., 1992, p. 120). Some of the prominent development ideas and ideals of Gandhi and his close associate Dr. J. C. Kumarappa, with a view to remind the government and the people about their relevance in the present context, our aggressive pursuit for 'destructive development,' without caring for the environment or 'Nature' in general on one hand and in the context of the currently ongoing process of decentralization and local development on the other. The decentralized development planning and local level development, currently being adopted after the 73rd Constitutional Amendment in India, should have adopted, to the extent possible, lessons from the Gandhian concept of 'Grama Swaraj.' (Pillai, 2018)

\section{Bread Labor}

According to Gandhi, each man must do physical labor to earn his bread. Physical labor is necessary for moral discipline and for the sound development of the mind. Intellectual labor is only for one's own satisfaction and one should not demand payment for it. The needs of the body must be supplied by the body (Madhumathi, 2011). Modern science has also recommended physical exercise for a healthy life so one should work on the agricultural field or cottage industry for basic needs, whoever the person is. According to him, one who does not work will not have the right to his bread. Even Lawyers, Engineers, Scientists, Professors, Poets, and Playwrights will have to perform physical labor apart from their intellectual labor to earn their upkeep, they will not demand any payment or compensation for their intellectual labor, it serves only to satisfy intellectual or the self-soul.

\section{Cottage Industries}

Gandhi stressed the need for cottage and small industries in place of gigantic industries and advocated for a decentralized economy instead of a centralized one. He realized the need for integrated Community development and believed that education, health, and vocation should be properly integrated for people. Swadeshi is the moral principle underlying a decentralized selfsufficient economic structure that is advocated. According to Gandhi, Swadesh is that spirit in us which restricts us to the use and service of our immediate surroundings to the exclusion of the more remote (Patil, 1983). Gandhi emphasized indigenous industries to produce like Khadi, soap making, paper making, matchmaking, oil pressing, etc. In the local industries, people are to engage themselves in their homestead (Mishra, 2015). The Gandhian model also formed the basis 
of traditional, small-scale, Community household-based cottage industries using local resources, without external injections of finance or displacement of labor (Yuko \& Balaji, 2018).

\section{Cooperatives}

Even in the field of community development and agriculture, Gandhi recommended co-operative farming. It would save labor, capital, tools, and provide employment to all adult locals and increase productivity. He said that we must attempt to prevent further fragmentation of agricultural land and encourage people to initiate co-operative farming. He noted that when dependence becomes necessary in order to help society to maintain good order it is no longer dependence but it becomes cooperation He also favored spinners co-operatives and co-operative cattle farming for promoting the national interest (Panday, 1991, p. 43).

\section{Trusteeship}

According to Gandhi, trusteeship is a way of life rather than just a method to achieve a particular end. According to his holistic approach, "everything on the earth belongs to God and is from God. Therefore, it was for these people as a whole not for a particular individual. Everybody on this earth has a natural right to at least the basic necessities of life, just like the birds and the beasts have. An individual had more than his proportionate share or more than what exactly need, he was a trustee of that portion for God's people" (Patil, 1983, p. 138). Gandhi viewed it as sin if our fellow beings are hungry and we are living a luxurious life. We should try to live in peace and harmony and develop a sharing habit at least at our own end then truly we will be following Gandhian ideology otherwise if talk of his ideology but adopt a highly individualistic approach without caring for others then we are doing sin in which is exhibited in a high level of corruption, scams and scandals, economic inequalities. India should learn to live with a moderate growth rate but with lower corruption, inequalities, inflation, and crime. It is seen that a high level of growth is followed by more corruption. As wants are unlimited Gandhian Philosophy endorses self-control and limitation of desires which is in turn based on Hindu Philosophy as the saying goes "Santosham Parmam Sukham" (Upadhyaya, 2015). The trusteeship that he spoke of is seen as a model for corporate governance and increasingly spoken of in the context of the rising global inequality. The vulnerability felt by some and the threat felt by others in the unequal space today is a testimony to the apprehension that Gandhi had for the ownership model and the Trusteeship model that he posed as its antidote. "Trusteeship is founded on the sovereignty of truth and an incessant striving after its completeness. The theory of trusteeship is an inclusive, non-violent worldview that regards every human being as an active, contributing agent for the promotion and progress of all". The world debates and has set for itself addressing inequality as one of its Sustainable 
Development Goals (SDG -5). However, there is very little in terms of a comprehensive model available anywhere for this because the foundational economic paradigm is rooted in violence rather than non-violence (Venkatesh, 2019). Trusteeship is Gandhi's unique conceptualization of a bridge between labor and capital despite being contradictory to each other. Seeking to understand them as being complementary to each for meaningful socio-economic development and political understanding, the Mahatma evolved his own model of a relationship that is based on trust by the workers for the indigenous industrialists (Chakrabarty, 2017).

\section{Cleanliness}

Gandhi was much ahead of his time is reflected through his life and work he made futuristic statements on environment and development. Gandhi was deeply distressed by the public squalor that he saw around him. It represented a clear indication of a lack of respect for others. In a speech at the Hindu University Central College, in Banaras in 1916, he said: If even our temples are not models of roominess and cleanliness, what can our self-government be? It is not known the elementary laws of the cleanliness of the people. We spit everywhere on the (railway) carriage floor, irrespective of the thought that it is often used as sleeping space. Applying Gandhian notions in day to day activities can make the lifestyle of society more comfortable and happy. It would be able to check environmental degradation and hence would achieve sustainability. Thus, there is a great concern about the environment in Gandhian Philosophy and Practices (Upadhyaya, 2015). The root cause of environmental degradation lies in the fast industrialization and obsession for material development though it has given human society material pleasure and prosperity. The factors responsible for environmental degradation due to over-exhaustion of resources through artificial means continue to aggravate the situation with a much faster pace than the effort to recover and conserve it. Gram-swaraj as defined by Gandhi was a developmental model for India even before independence. This alternative notion of development or the best alternative to development that is critical of Western modernity and industrialization that can offer valuable insights for India in this post-liberalization period of Gandhian time (Gopika, 2020).

\section{Community Reconstruction through removal of untouchability}

According to Vedic philosophy and Bhagavad Gita, entire souls are equal. All souls are the same children of the almighty nature. So the untouchability must be eradicated. Untouchability is a social evil. It should not be looked upon as a mere political necessity. The socio-economic evils and malpractices associated with this system must be abolished in Community areas. According to Gandhi, there should be perfect social equality and equity as well among the people in society. No social superiority or inferiority should be entertained by any individual or by a section of 
the society on the basis of birth or knowledge or religion or any other. Gandhi was the second Buddha. Belief in Sarvodaya and Vasudhaiba Kutumbkam considers "One World", therefore, Gandhi ignored the concept of narrow nationalism and wanted progressive internationalism. There is a need to look at the problems, from the international viewpoint and thus seek holistic solutions (Upadhyaya, 2015). Gandhian Peace, Tribal, Anti-liquor movements, are based on peace and security in local places. All of these separately and collectively create conditions, for peace to originate and sustain in the true sense of the term, and hence are known as peace movements, or human rights movements in another way (Rawat, 2020). so, we can claim him as a second Buddha.

\section{Training (Nai Taleem)}

Gandhi and India had no faith in the modern education system, which emphasized only literacy and acquisition of information. He developed a new system of appropriate education and training for the people. He believed that it would help to develop the full potential of children and adults, through the development of bodies, minds, and spirits. He wanted to see it to be selfsupporting and practice-oriented in the field of Community development. Liberal studies focus on skills, human life, critical thinking, and creativity and thus broadens the choice of profession and occupation a person can take with a better understanding of self and the world of modernity. Mahatma Gandhi the spiritual and conscious leader of India developed and practiced a philosophy of education called 'Nai Talim' -translated as new training or learning- which focused on the allround development of humans like various skills, knowledge, arts, wisdom, and above all morality and making them responsible citizens of the local. This system has been in practice in various institutes successfully even in the 21st Century (Vaishnav, 2019)

\section{Sustainable Development}

In order to achieve targets of Community development, developing and developed countries are irrationally exploiting their natural resources without concerns and understanding of how to exploit and when to exploit them. Our lives are widely dependent on the availability of natural resources and their exploitation. If correct balanced is a strike between the usage of resources and availability of resources than the lives of people and the integrity of the planet could be managed well. However, when life is turned into excessive luxury and comfort this balance could break and creates a disaster. The concept of sustainable development is multi-dimensional and multi-modal but it is based on local requirements. Use and Throw is not applicable for sustainable development while Reduce- Recycle-Reuse is the best concept of sustainable development to a balancing of needs and usage (Gupta, 2015). Sustainable development means the fulfillment of the present needs without compromising the needs of the future generation. Mahatma Gandhi's 
way of living is the best example of sustainable development for the world. In Mahatma Gandhi's words that earth provides enough to satisfy every man's need but not any man's greed. The 2030 Agenda for Sustainable Development, wherein 193 United Nations Member States pledged to ensure 'no one will be left behind' and to 'endeavor to reach the furthest behind first' also reflects this Gandhian philosophy (Reddy, 2019). Thus these core values must be analyzed in any community development program.

\section{Theoretical and Conceptual Framework}

Theoretically, the Gandhian approach to community development may be labeled as 'idealist'. It attaches supreme importance to moral values and gives primacy to moral values over material conditions as thought by Gandhi. The Gandhians believe that the source of moral values in general lies in spiritualism, religion, and Hindu scriptures like the Upanishads and the Gita, in particular. These texts are semi-scientific. The concept of 'Ram Rajya' is the basis of Gandhi's idea of an ideal social order, it can be said a symbol of Good Governance. Gandhi defined Ram Rajya as it is the sovereignty of the people based on moral authority at the local level. He did not view Rama as a king, and people as his subjects but a symbol. In the Gandhian thought, 'Ram' stood for God or one's own 'inner voice'. Gandhi believed in a democratic social order in which people and people's verdict of representations are supreme. It is subject to moral values (Madhumathi, 2011). However Gandhian thought is based on the philosophy of Universalism. Universalism is the norms and values accepted by the entire Universe. The common acceptance of the people of the Universe is universalism. The Universal Truths are the Gandhian Truths. Whatever we observe, there are only three universal truths in the basket of this huge universe. The first one is birth that is creation also known as Generation. The second universal truth is the operation of the Creation or Generation. It works and grows old. The third universal truth is death. Whatever was born has to operate and die. It is also called Destruction. Thus in a basket that contents Generation, Operation, and Destruction of this nature is GOD. Gandhi believes in God and God is the universal truth or mother nature. The theoretical base of the Gandhian Model of Community Development (GMCD) is Universalism. God is almighty nature and its functional mechanism. Gandhi, who considered the earth a living organism, understood nature and existence in terms of a Cosmic Law that entails that the universe is a single self-coherent all-encompassing entity, organized and animated by a cosmic spirit wherein all life and all existence are one. As a proponent of the monistic (non-dualist) Indian philosophical system of Advaita, he believed in the essential unity of man and nature (Upadhyaya, 2015). The philosophy is guided by Shrimad Bhagavad Gita. He was highly influenced by popular authors like Ruskin and Tolstoy of that contemporary time. 
Mahatma Gandhi who in the first decade of the twentieth century (1908- at the time of publication Hind Swaraj) understood the unsustainability of modern civilization based on the multiplication of wants and desires (Sahu, 2016). The late Gandhian Historian Sri. Dharampal once rephrased this Gandhian view, as the way of Indian life thus, "that which is great about this country is that the ordinary people of this country have understood that all things in life are connected and they have built their life around this understanding" Dalit Sarpanch near Chennai explicitly combines both Gandhian and Marxist principles in his attempt to transform the local he lives in, including providing more dignity and livelihood security to Dalit families. Gandhian concept of Gram Swaraj indicators or Marxist's tradition of social analysis, based on social structure and class analysis; and a third set could take a normative perspective such as in the popular Human Development indicators (HDI) of the UNDP.

Conceptually it is a Hermeneutic interpretation of Historical facts of Mahatma Gandhi in action from a sustainable approach in a hermeneutic circle given by Gadamer. With phenomenology and existentialism, it was also one of the twentieth century's most important philosophical movements and included major thinkers such as Heidegger, Gadamer, and Ricoeur.

\section{Critical Analysis}

The critics argue that Gandhi's ideals of swadeshi, voluntary curtailment of one's wants, trusteeship, self-sufficient locals, and use of manual labor in preference to machines sound obsolete these days, particularly in the weeks of India's new economic policy characterized by privatization, liberalization, and globalization (Madhumathi, 2011). As a matter of fact, by adopting an economic growth-oriented development part and by following the Western model of industrialization, both under the influence of Jawaharlal Nehru, India had abandoned the Gandhian model long ago, they assert further. To conclude it could have been said that Gandhi wanted India to travel east, but India decided to travel west, and it is known that 'the twain never meet'. Gandhi maintained that industrialization would help only a few and will lead to a concentration of economic power. Industrialization leads to the passive or active exploitation of the locals. It encourages competition. Large scale production requires marketing. Marketing means profit-seeking through an exploitative mechanism. The Gandhian path of development would have been the most appropriate choice of the first Government at the time of Independence. Unfortunately, this Government under Jawaharlal Nehru never accepted Gandhian prescriptions for economic development (Pillai, 2018).

\section{Gandhian Model of Community Development Indicators(GMCDI)}

From the analysis of basic norms, values and literatures following indicators are identified to 
evaluate the status of community development of a particular local council, Panchayat in India and Palika in Nepal. The interlinkages and integrated nature of the Sustainable Development Goals are of crucial importance in ensuring that the purpose of the new agenda is realized. If we realize our ambitions across the full extent of the Agenda, the lives of all will be profoundly improved and our world will be transformed for the better (UN, 2019) and it is based on need not in greed. The following indicators will be appropriate allowing with 17 sustainable goals. The following points must be addressed by a local or municipality.

a) There should be orderliness in the structure of the local. b) It should have fruit trees. c) It should have a Dharmashala and a small dispensary. d) It should be self- sufficient in so far as food and clothes are concerned. e) The roads and lanes of the local should be kept clean so that in the land of bare-footed pedestrians' nobody should hesitate to walk. f) The temple/ mosque should be kept beautifully clean $g$ ) The local should be capable of defending itself from robbers and wild animals. h) The local should maintain a public hall, a school and a theatre hall. i) It should have an efficient water supply arrangement. j) It should have recreation facilities- a playground, a reserve for the cattle, etc. $k$ ) If some space is left, it should grow many crops except tobacco, opium, etc. I) Education in the local should be made compulsory up to the final basic standard. m) All activities of the local should be conducted on co-operative lines. n) The government of the local should be conducted by a panchayat of five persons duly elected every year by adult localrs o) The local panchayat would enjoy judicial, legislative and executive power. p) The service of local guards should be compulsory and they should have selected by rotation. q) The caste system should not be practiced (Chutia, 2019).

From the points above we can draw the indicators of the community development. The following points specified in table are the basic indicators. "The economic development model should be employment oriented, rather than production oriented" is the basic foundational assumption of the study.

\section{Gandhian Model of Community Development Indicators}

GMCDI of ............. Municipality as on .......

\begin{tabular}{|l|l|l|l|}
\hline SN & Details & Numbers & Ratio to population \\
\hline 1 & Ambulances & & \\
\hline 2 & Campuses & & \\
\hline 3 & Community Festivals & & \\
\hline 4 & Cooperatives & & \\
\hline
\end{tabular}




\begin{tabular}{|l|l|l|l|}
\hline 5 & Cottage Industry & & \\
\hline 6 & Doctors & & \\
\hline 7 & Elected legislative of Local body & & \\
\hline 8 & Elected Marginalized Community & & \\
\hline 9 & Elected Women of Local Body & & \\
\hline 10 & Farmers & & \\
\hline 11 & Farmers (BA and above Passed) & & \\
\hline 12 & Hospital Beds & & \\
\hline 13 & Laborers & & \\
\hline 14 & License of weapons & & \\
\hline 15 & Local language & & \\
\hline 16 & Local Souvenir Icons & & \\
\hline 17 & Plants Run by Women & & \\
\hline 18 & Sanitation(Number of Projects) & & \\
\hline 19 & Schools & & \\
\hline 20 & Schools (Religious Clubs) & \\
\hline 21 & Temples/ Mosques / Churches & & \\
\hline 22 & Teachers & & \\
\hline 23 & Training Projects of Municipality & & \\
\hline 24 & Trusteeship (Guthi/ CBOs/NGOs) & & \\
\hline 25 & Unemployment & & \\
\hline 26 & Differently able & & \\
\hline 27 & Vegetarian population & \\
\hline
\end{tabular}

(Specimen of Indicators)

From the table we can evaluate essential elements of local that are required for the betterment of local life. It is the tool to check the reality of the local and its direction toward the expected changes. Above stated 27 points clearly gives the status of a local territory from Gandhian Model of Community Development. The concentration of human habitats into urban pockets is a process of centralization that is a corollary to the urban-centric model of growth and development. Localized, self-reliant, community-centric and community empowering initiatives have evolved exemplary models have all originated from Gandhian roots.

\section{Balance Sheet of Nature and Human}

Nature and Human Balance Sheet is a tool to evaluate production and import over consumption 
and export of local bodies. The main assumption of this balance sheet is that there must be balance among production and consumption in a particular local within a specified geography.

\section{Balance Sheet of Nature and Human}

Of Community Municipality of year.

\begin{tabular}{|l|l|l|l|l|l|l|l|l|l|l|l|}
\hline \multirow{2}{*}{ SN } & \multirow{2}{*}{ Details } & \multicolumn{3}{|l|}{ Production and Import } & \multicolumn{3}{l|}{ Consumption and Export } & \multicolumn{3}{l|}{ Surplus/Deficit } \\
\hline & & Unit & Rate & NRs. & Unit & Rate & NRs. & Unit & Rate & NRs. \\
\hline 1 & Cloths & & & & & & & 0 & & \\
\hline 2 & Electronics & & & & & & & 0 & & \\
\hline 3 & Energy & & & & & & & 0 & & \\
\hline 4 & Fish/Meats/Egg & & & & & & & 0 & & \\
\hline 5 & Food cereals & & & & & & & 0 & & \\
\hline 6 & Fruits & & & & & & & 0 & & \\
\hline 7 & Groceries/Milk & & & & & & & 0 & & \\
\hline 8 & Tourists & & & & & & & 0 & & \\
\hline 9 & Tools & & & & & & & 0 & & \\
\hline 10 & Vegetables & & & & & & & 0 & & \\
\hline & Total & & & & & & & 0 & & \\
\hline
\end{tabular}

(Specimen of Balance Sheet)

By the aid of the table, a municipality can evaluate its internal production and consumption of the people of the area. It shows the status of the self-sustainability of the area. Overproduction means overexploitation of resources. Overconsumption is not healthy. It must be in balance. The surplus is for others. Sustainable development has been the driving force in my political life for more than forty years. Globally, 73 percent of children under 5 have had their births registered (UN, 2018). Only 45 percent of the world's population is covered by at least one social protection cash benefit. Economic losses attributed to disasters were over \$300 billion in 2017. World hunger is on the rise again: 815 million people were undernourished in 2016, up from 777 million in 2015. The 17 Goals and 169 targets of Sustainable Development demonstrate the scale and ambition of this new universal Agenda. To build on the Millennium Development Goals and complete what these did not achieve and to realize the human rights of all and to achieve gender equality and the empowerment of all women and girls. The goals and targets are integrated and indivisible and balance the three dimensions of sustainable development: the economic, social, and environmental (Hambrey, 2017). The sustainable development goals 
specified by the United Nations are seventeen in Number. These seventeen goals are categories in 5Ps of sustainable development. They are People, Planet, Prosperity, Peace, and Partnership. These are the conceptual variables of $5 \mathrm{ps}$ of Sustainable development. The need of the hour is to create consciousness about conserving natural resources and preserving our environment, eventually suggesting an economy not leading to an economy of violence. Such elements are embedded in the genesis of Gandhian thoughts and J.C. Kumarrapa's notion of the non-violent economy (Sharma P., 2018).

\section{Gandhian Model of Community Development}

To make a "model" and then to scale it up or replicate it is an idea from the shop floor-based industry. Perhaps the first project of "Model Local" in Independent India was called the Etawah pilot project that was promoted by an American Town Planner, Albert Meyer. The project itself was conceived to prove the 'advanced' agricultural and animal husbandry technology of Americans and as such irked the Gandhian followers such as J.C. Kumarappa, JP, and Kripalani because it was more focused on proving the technology and less to do with land reforms or the self-government or regional food self-sufficiency (Ramesh \& Shivaram, 2019). The concept and approaches to the study of a model local can be perplexing unless one delimits within the safety of a framework of a local. The present consumerist society has promoted non-essential consumers through clever and brainwashing advertisements and these non-essential commodities are acceptable as essentials are the major drawbacks. It has a negative impact on human psychology, social structure, and the ecosystem (Tiwari, 2020). He wrote in Hind Swaraj that the mind is a restless bird; the more it gets the more it wants, and still remains unsatisfied- strange. The more we indulge our passions the more unbridled they become, we must drive our mind. Our ancestors, therefore, set a limit to our indulgences related to material wants and desires. They saw that happiness largely a mental condition. A man is not necessarily happy or unhappy because of his rich or poor status. The rich are often seen to be unhappy, the poor to be happy because small is beautiful. Millions will always remain poor because capital attracts capital. Observing all this, our ancestors dissuaded us from luxuries and pleasures to enjoy in nature. Thus the philosophy of modernity is on the wrong track.

\section{Conclusion}

Gandhi advocated that production must be based on need instead of greed. He found the current economic structure based on greed and quantity. In conclusion, development is a continuous process, it will be achievable up to a fixed point of target and it starts again. It is directly related with human wants and theory of motivation. It is unlimited as the human needs are unlimited. Thus the prudential decisions are to drive the mind toward sustainable development. Simply we have to set 
a goal follow and achieve that then set next achieve that be happy on achievements and future courses of action. At the beginning human starts to work(Karma), by the good karma- sometime Kama i.e. conjugal relation. and hard work earns some money (Artha). Then the Artha should be mobilized to Dharma and the Dharma lead toward Liberation the Moksya. Thus Gandhian Model of Community Development is based on oriental conviction of Liberation is equivalent of ultimate Development- Moxya. Moxya is possible with balance in life in the tenants of peace and nonviolence. Thus, from the Gandhian view, Community Development is the balance of human production and consumption to protect mother nature in Community area with entire human norms and values. The model is useful for local, provincial, and federal governments around the globe. Community development indicators can be used to compare and analyze the status of different communities and further community development planning and problem identification.

\section{References}

Amoroso, L. (2015). Hermeneutics as a new science. In J. Malpas, \& H.-H. Gander, The Routledge Companion to Hermeneutics (pp. 215-223). New York City, NY: Routledge.

Badal, B. P. (2017). Social Welfare Model of Community Development . Nepalese Journal of Development and Community Studies, 14 (1\&2), 1-11.

Chakrabarty, B. (2017). Gandhi's Doctrine of Trusteeship: Spiritualizing Interpersonal Relationship. Nabakrushna Choudhury Centre for Development Studies.

Chutia, S. (2019). Gandhiji's Approach to Community Development in Present Time Context. International Journal of Research in Economics and Social Sciences (IJRESS) 8.2, 14-18.

Colucci-Gray, \& Camino, L. (2016). Looking Back and Moving Sideways: Following the Gandhian Approach as the Underlying Thread for a Sustainable Science and Education. . Visions for Sustainability, 6: 23-44.

Cush, D., Robinson, C., \& York, M. (2008). Encyclopedia of Hinduism. UK, London: Routledge.

Deliyannis, D. M. ( 2003 ). Historiography in the Middle Ages . Koninklijke Brill NV, Leiden, The Netherlands.

Gelina, H., Nikos, K., Kostas, S., \& Vaiopoulos, V. (2010). The new ways of History: Developments in Historiography. Tauris Academic Studies: Palgrave Macmillan, 175 Fifth Avenue, New York NY 10010.

Gopika, G. (2020). Significance of Gram-Swaraj in Neoliberal India: Re-inventing Gandhi's concept 
of Economic Decentralization. Studies in Indian Place Names (UGC CARE Journal) 40.24, 160-165.

Gupta, I. (2015). Sustainable Development: Gandhi Approach. OIDA International Journal of Sustainable Development, 8.7, Available at SSRN: https://ssrn.com/abstract=2667226, $27-32$, .

Hambrey, J. (2017). The 2030 Agenda and the Sustainable Development Goals: The challenge for aquaculture development and management. FAO Fisheries and Aquaculture Circular No. 1141, Rome, Italy.

Madhumathi, M. (2011). The Gandhian Approach to Community Development. International Journal of Creative Research Thoughts (IJCRT) www.ijcrt.org, 59-70.

Mishra, C. R. (2015). Gandhian Economic Model as an Alternative. Gandhiji, Gram Swaraj, Decentralisation, 27-38.

Palanithurai, G. (2019). Looking at the Decentralization from Gandhian Action Perspective . Journal of Community Development, 38.3, 452-465.

Panday, B. (1991). Gandhlhi and Economic Development. New Delhi: Radiant Publishers.

Patil, S. (1983). Gandhi and Swaraj. New Delhi: Deep and Deep Publications.

Pillai, P. P. (2018). Relevance of Economic Ideas and Ideals of Mahatma Gandhi and J.C. Kumarappa in Today'sContext of Decentralization and Development. Gandhi Marg Quarterly 40(1\&2), 73-90.

Pitcher, L. ( 2009 ). Writing ancient History: An introduction to classical histeriography. New York NY 10010: I.B.Tauris \& Co Ltd .

Prabhu, R., Rao, U., Bhave, B., \& Radhakrishnan, A. (1967). The Mind of Mahatma Gandhi : Encyclopedia of Gandhi's Thoughts. Ahmedabad: Navajivan Mudranalaya.

Ramesh, R., \& Shivaram, P. (2019). The Idea of Model Local: Towards Developing a Framework to the Study of Model Local. Journal of Community Development, 38.3, 525-540.

Rawat, R. K. (2020). Gandhian Model of Protest: Four Case Studies. Journal of Xi'an University of Architecture and Technology 7.6, 1998-2009.

Reddy, W. (2019). Forewords. Journal of Community Development, 38.3. 
Sahu, S. N. (2016). Mahatma Gandhi and Sustainable Development. Odisha Review, 6-14.

Sharma, P. (2018). A Decentralized Pathway for Energy Security and Energy Transition in Developing Nations. Gandhi Marg Quarterly 40(1\&2): 57-72, 57-72.

Sharma, S. P. (1992). Gnndhian Holistic Economics. New Delhi,: Concept Publislung Co.

Tiwari, A. K. (2020). Gandhian Development Model as an Alternative Development Model in PostCOVID-19 Indian Economy. International Journal of Science and Research (IJSR), 348-354.

Tucker, A. (2009 ). A Companion to the Philosophy of History and Historiography. The Atrium, Southern Gate, Chichester, West Sussex, PO19 8SQ, United Kingdom: Blackwell Publishing Ltd. .

UN. (2018). The Sustainable Development Goals Report 2018. New York, NY: United Nations publication issued by the Department of Economic and Social Affairs .

UN. (2019). Global Sustainable Development Report 2019: The Future is Now-Science for Achieving Sustainable Development. New York: United Nations.

Upadhyaya, M. (2015). Gandhian Model towards Sustainable Development. Lakhanaw: Degree college, Department of Economics.

Vaishnav, H. (2014). Gandhi's Hind Swaraj and Sustainable Development. Ganpat University Journal of Applied Research In Social Science \& Humanities. 03, 01. 42. .

Vaishnav, H. (2019). Gandhi's Nai Talim and Liberal Studies: A Comparative Study of the two Models of Education. International Journal of Reviews and Research in Social Sciences. 7.3, 627-632.

Venkatesh, R. (2019). Gandhi in the 21st Century. Journal of Community Development, 38. 3, 514524.

Yesu, S. R., \& Muthupandi, P. (2016). Gandhian approach to Community development. National Journal of Multidisciplinary Research and Development, 38-41.

Yuko, A., \& Balaji, P. (2018). When both the state and market fail: inclusive development and social innovation in India. Area Development and Policy, DOI: https://doi.org/10.1080/2379294 9.2018.1481759.

Zimmermann, J. (2015). Hermeneutics: A Very Short Introduction. United kingdom: Oxford University Press 